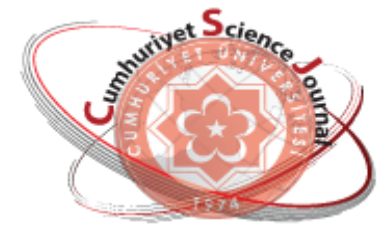

e-ISSN: $2587-246 X$

ISSN: $2587-2680$

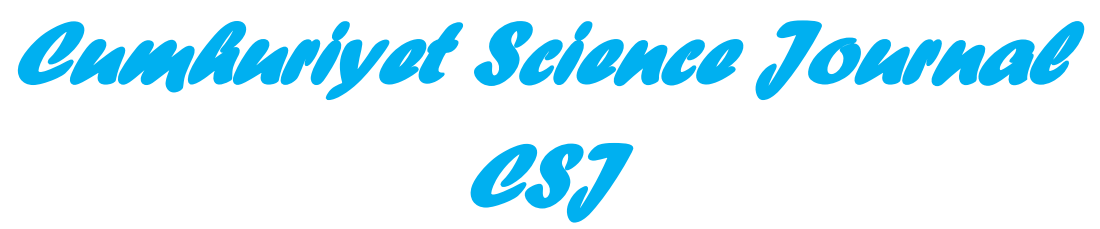

Cumhuriyet Sci. J., Vol.40-2(2019) 275-284

\title{
A Simple and Cheap Ultrasound-Assisted Microextraction Procedure For Extraction of Tartrazine in Soft Drinks and Foodstuff
}

\author{
Nail ALTUNAY ${ }^{1}$

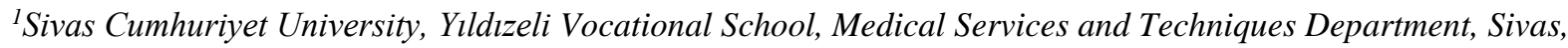 \\ Turkey
}

Received: 20.12.2018; Accepted: 22.02.2019

http://dx.doi.org/10.17776/csj.499721

\begin{abstract}
In this study, a simple and cheap ultrasound-assisted ionic liquid-based floating organic droplets microextraction (UA-IL-FODME) has been proposed for spectrophotometric determination of synthetic food dye (tartrazine) in soft drinks and food samples. 1-Octyl-3-methylimidazolium tetrafluoroborate [C8MIM][BF4] and 1-octanol were used as the extraction solvent and dispersant solvent, respectively. The method is based on extracting the tarrazine to the ionic phase with the help of ultrasonic effect at $\mathrm{pH}$ 5.5. Some experimental variables $(\mathrm{pH}$, ionic liquid amount, type and volume of dispersive solvent, and ultrasonic conditions) were studied and optimized in detail. In optimum conditions, some analytical parameters of the method were as follows. Operating range, limit of detection, preconcentration factor, recovery \% and RSD \% values were 10-700 $\mu \mathrm{g} \mathrm{L}-1,3.2 \mu \mathrm{g} \mathrm{L}-1,75,94.7-104.7 \%$ and 2.7\%, respectively. Following comprehensive validation studies, the recommended method was successfully applied to the extravasation and determination of tartrazine in soft drinks and foodstuff.
\end{abstract}

Keywords: Floating organic droplets, Ionic liquid, Ultrasound, Tartrazine, Soft drinks, Foodstuff.

Alkolsüz İçecekler ve Gıda Ürünlerinde Tartrazinin Özütlenmesi için Basit
ve Ucuz Ultrason Destekli Mikroekstraksiyon Prosedürü

Özet. Bu çalışmada, basit ve ucuz ultrason destekli iyonik sıvı bazlı yüzer organik damlacıklar mikroekstraksiyonu (UA-IL-FODME), sentetik yiyecek boyalarının (tartrazin), alkolsüz içeceklerde ve gıda ürünlerinde spektrofotometrik olarak belirlenmesi için önerilmiştir.1-Oktil-3-metilimidazolyum tetrafloroborat [C8MIM] [BF4] ve 1-oktanol sırasıyla ekstraksiyon çözücü ve dağıtıcı çözücü olarak kullanılmıştır. Yöntem, pH 5.5'te tarrazin 'in iyonik faza ultrasonik etki yardımıyla özütlenmesine dayanır. Bazı deneysel değiş̧enler (pH, iyonik sıvı miktarı, dispersiv çözücü çeşidi ve hacmi ve ultrasonik koşullar) çalışıldı ve ayrıntılı olarak optimize edildi. Optimum koşullarda, yöntemin bazı analitik parametreleri aşağıda özetlenmiştir. Çalışma aralığ 1 , seçme sınırı, ön konsantrasyon faktörü, geri kazanma yüzdesi ve \%BBS değerleri sırasıyla 10-700 $\mu \mathrm{g}$ L-1, $3.2 \mu \mathrm{g} \mathrm{L}-1$, 75, \% 94.7-104.7 ve \% 2.7 idi. Kapsamlı validasyon çalışmalarının ardından, önerilen yöntem, alkolsüz içecekler ve gıda maddelerinde tartrazininekstraksiyonu ve tayinine başarıyla uygulanmıştır.

Anahtar Kelimeler: Yüzen organik damlacıklar, İyonik sıvı, Ultrason, Tartrazin, Alkolsüz içecekler, Gıda ürünleri. 


\section{INTRODUCTION}

In the world, food production and consumption are increasing due to population growth. Food additives should be used to prevent food spoilage during transportation and storage. [1]. Food dyes are defined by the International Food Codex Commission as additives to regulate the color of the dish. [2]. Nowadays, for technological reasons, it is suggested that foods should be colored [3]. Synthetic colorants are substances which can be produced by chemical synthesis. Synthetic colorants provide superiority in terms of color strengths, color ranges, stability, ease of use and price compatibility according to natural colorants. [4]. Tartrazine is water soluble synthetic food dye and its code is E102. Food additives are widely used for different purposes, including preservation, coloring and taste. However, some food additives are prohibited due to their toxicity [5]. Among the five azo dyes, Amaranth, Allura Red, New Coccine and Tartrazine (initially $10 \mathrm{ppm}$ ) lead to doserelated DNA fragmentation in the colon [6]. Tartrazine can cause allergic and asthma problems in delicate people. The analytical control of these compounds is important for the food industry due to their toxicity and carcinogenicity [7]. Therefore, simple, inexpensive and fast analytical methods are needed to determine synthetic dyes in food. Analytical methods for the analysis of synthetic colorants in food and beverages have been reported in literature. These methods are based on the basis of the thin layer chromatography (TLC) [8], high performance liquid chromatography (HPLC) with diode array detection (DAD) and ion-trap time-offlight mass spectrometry (IT-TOF/MS) [9], spectrophotometry [10], electrochemical sensor [11], high performance liquid chromatography (HPLC)-diode array detector (DAD)-electrospray mass spectrometry (ESI-MS) [12]. It is also necessary to minimize possible matrix effects when analyzing at low levels. Therefore, different extraction methods such as solid phase extraction (SPE) [13], liquid-liquid extraction (LLE) [14], cloud point extraction (CPE) [15], molecularly imprinted solid-phase extraction (MISPE) [16], ultrasound-assisted extraction (UAE) [17-19] and ionic liquid based liquid phase microextraction (IL-
LPME) [20-22] were applied before determination step. In addition to these extraction methods, in the recent years, extraction methods using ionic liquid (IL) have become popular. Some of ILs properties are low toxicity, high vapor pressure, biodegradable and high hydrophobicity.

The purpose of this study is to develop a simple and cheap analytical method for the determination and extraction of tartrazine in soft drinks and foodstuff. In this context, the ultrasonic-assisted ionic liquidbased floating organic droplets microextraction procedure (UA-IL-FODME) was developed and UV-VIS spectrophotometry was used in the determination step. Factors affecting the extraction of tartrazine were investigated in detail. The proposed method can be applied for determination of tartrazine in soft drinks and foodstuff. After routine applications, the results shown that the proposed method is suitable for the extraction and determination of tartrazine in different food samples.

\section{MATERIALS AND METHODS}

\subsection{Apparatus}

In the study, tartrazine content in selected samples was determined at $425 \mathrm{~nm}$ using Shimadzu brand UV-VIS spectrophotometry (UV-1800 PC model, Kyoto, Japan). Ultrapure water with resistivity of 18.2 $\mathrm{M} \Omega \mathrm{cm}$ was obtained by a Milli-Q water purification system (Millipore Corp., USA). Extraction of tartrazine from sample solution was achieved by a universal hettich brand centrifuge (Hettich, London, England). The pH of samples solution was adjusted using a digital $\mathrm{pH}$ meter (Sartorius Docu-model, North America). An ultrasonic bath (UCS-10 model, Seoul, Korea) was used for both sample preparation and the formation of microsphere of ionic liquid.

\subsection{Chemical and Reagents}

The reagents used were of analytical purity, and were purchased from Sigma (St. Louis, MO. USA) and Merck (Darmstadt, Germany). The stock solutions of tartrazine (Sigma) was prepared in water. Working standards were prepared by dilution of the stock solution. 1-Octyl-3- 
methylimidazolium

tetrafluoroborate ([C8MIM][BF4]) (Sigma) was used as extraction solvent. Acetone (Merck), 1-heptanol (Merck), 1octanol (Merck), ethanol (Sigma), 2-propanol (Sigma), and methanol (Merck) were tested as dispersive solvents. $\mathrm{pH} 5.5$ of acetate buffer solution $(0.1 \mathrm{M})$ was prepared by mixing an appropriate amount of sodium acetate and acetic acid in water. Before the experiment, all materials were washed in dilute nitric acid, followed by rinsing three times with distilled water, respectively.

\subsection{Sample collection and preparation}

Soft drinks and foodstuff were collected randomly from the local markets in Sivas, Turkey. Ultrasonic-assisted sample preparation step was carried out as follows: First, $50 \mathrm{~mL}$ centrifuge tubes were taken, and then $2 \mathrm{~g}$ of foodstuff and 3 $\mathrm{mL}$ of soft drinks were added to the tubes. Final volume of tubes was diluted to $50 \mathrm{~mL}$, were placed in ultrasonic bath, and then sonicated for $15 \mathrm{~min}$ at $30{ }^{\circ} \mathrm{C}$. The resulting mixture was filtered through the membrane filter after centrifugation at 4000 rpm for $5 \mathrm{~min}$. The same experimental steps were performed to the blank sample. The proposed method was applied to $1.0 \mathrm{~mL}$ of the prepared samples.

\subsection{UA-IL-FODME procedure}

The UA-IL-FODME procedure was performed in $15-\mathrm{mL}$ centrifuge tubes. First, an aliquot of $1.0 \mathrm{~mL}$ sample solution containing $25 \mu \mathrm{g} \mathrm{L}-1$ of tartrazine was added to the tubes. Then the $\mathrm{pH}$ of the sample solution was adjusted to $\mathrm{pH} 5.5$ with acetate buffer. To ensure the extraction of tartrazine from the sample solution, $400 \mu \mathrm{L}$ of [C8MIM][BF4] (extraction solvent) and $300 \mu \mathrm{L}$ of 1-octanol (dispersive solvent) were added rapidly with a micro syringe into the sample solution. The tubes were sonicated for $5 \mathrm{~min}$ at $45 \mathrm{oC}$ in the ultrasonic bath to form the microspheres of the [C8MIM][BF4].The tubes were centrifuged at $4000 \mathrm{rpm}$ for $2 \mathrm{~min}$, and then were stored in an ice bath to facilitate phase separation. At this stage, the dispersive solvent (1-octanol) was solidified within 2 min. After decantation, the remaining phase was completed to $500 \mu \mathrm{L}$ using ethanol. Finally, the amount of tartrazine was determined at $425 \mathrm{~nm}$ by UV-Vis spectrophotometry. A blank solution was also carried out using the same experimental steps without tartrazine.

\section{RESULTS AND DISCUSSION 3.1. Selection of working wavelength}

The most important step of the experimental studies using UV-Vis spectrophotometry is the selection of the measurement wavelength. Because all the experimental measurements were performed at the selected wavelength. If the correct wavelength is not selected, all experimental results are affected. Therefore, the following experimental steps were taken to determine the appropriate wavelength. First, only the tartrazine in the aqueous solution was obtained at the spectrum. Second, the spectrum of tartrazine in the presence of other chemicals was taken. The results were given in Figure 1. As the results show, the tartrazine spectrum gave a weak spectrum at 435 $\mathrm{nm}$, while in the presence of IL a sharp spectrum was obtained at $425 \mathrm{~nm}$. In addition, the absorbance of the obtained spectrum shows a linear increase with the concentration of tartrazine. These reasons were chosen as the appropriate wavelength of $425 \mathrm{~nm}$ for optimization and analysis.

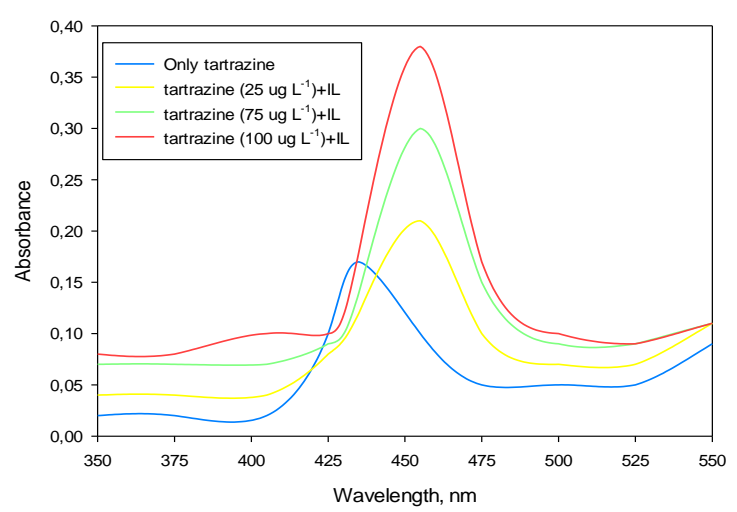

Figure 1. Absorbance spectra obtained in selected chemical conditions.

\subsection{Effect of $\mathbf{p H}$}

Electrostatic interactions between chemical species vary depending on the $\mathrm{pH}$ of the aqueous solution. In the extraction experiments, the interaction between the analyte and the selected chemical 
medium should be high. Depending on the interaction, the target analyte can be easily extracted from the aqueous solution. For a clearer view of this, the effect of the $\mathrm{pH}$ of the aqueous solution on the absorbance of tartrazine was investigated in the range of $\mathrm{pH}$ 3-9. As shown in Figure 2, the absorbance of tartrazine increased in the range of $\mathrm{pH} 3$ to 5.5 , and there was a decrease in absorbance at higher $\mathrm{pH}$ values. The reason for the decrease in absorbance at high $\mathrm{pH}$ is due to the loss of hydrogen from tartrazine. So, $\mathrm{pH} 5.5$ of acetate buffer was selected as the optimum $\mathrm{pH}$ for higher absorbance and easy phase separation.

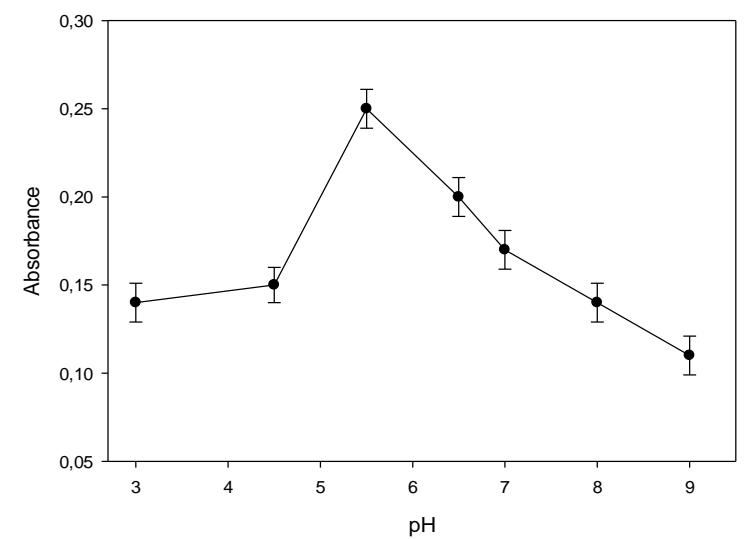

Figure 2. Effect of pH on absorbance of tartarazine

\subsection{Effect of [C8MIM][BF4] amount}

In these methods, the selection of the appropriate extraction solvent is necessary to good extraction. The following specifications should be taken into account when selecting the extraction solvent. (I) The selected solvent must be green. (II) A small amount of the extraction solvent should be sufficient for extraction. (III) the extraction solvent should be selective for the analyte. (IV) The extraction time should be short. Taking these properties into consideration, the ionic liquids (IL) such as [C8MIM][BF4] used in many fields were chosen as extraction solvents. The [C8MIM][BF4] must be in sufficient volume in the final volume in order to ensure the extraction. Therefore, the effect of the amount of [C8MIM][BF4] on the absorbance of the tartrazine was investigated in the range of 0 $800 \mu \mathrm{L}$. As shown in Figure 3, the extraction depend on the amount of [C8MIM][BF4. Phase separation was not achieved in the absence of
[C8MIM][BF4], and maximum absorbance was obtained when the [C8MIM][BF4] amount was $400 \mu \mathrm{L}$. So, $400 \mu \mathrm{L}$ of [C8MIM][BF4] was selected as the optimum value for higher absorbance and easy phase separation.

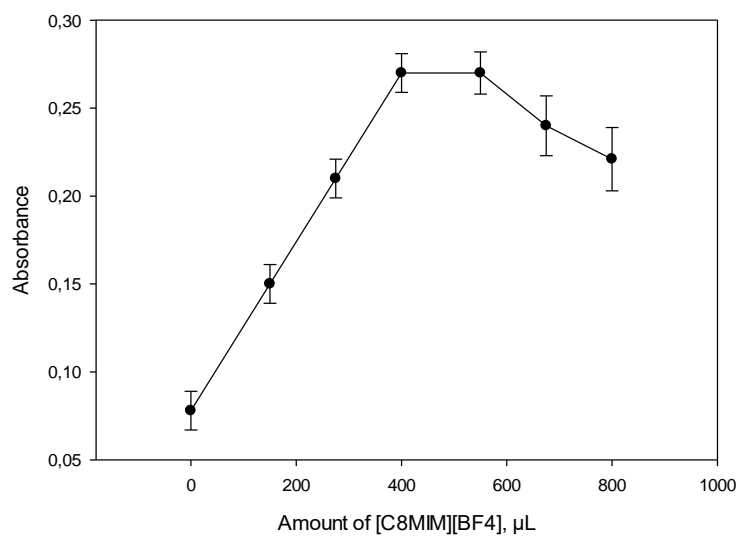

Figure 3. Effect of [C8MIM][BF4] amounton absorbance of tartarazine

\subsection{The effect of the type and volume of dispersive solvent}

The main purpose of the dispersive solvent is that the extraction solvent provides microsphere formation. The dispersive solvent should also be dispersible between the ionic liquid and the aqueous phase. For the selection of dispersive solvents, different solvents (acetone, 1-heptanol, 1octanol, ethanol, 2-propanol, and methanol) preliminary tests were made, and the best signals and phase separation were obtained in the presence of 1-octanol. So, 1-octanol was chosen as the dispersive solvent. The effect of the amount of this dispersive solvent on the absorbance of tartrazine was investigated in the range of $0-600 \mu \mathrm{L}$. The results were given in Figure 4.

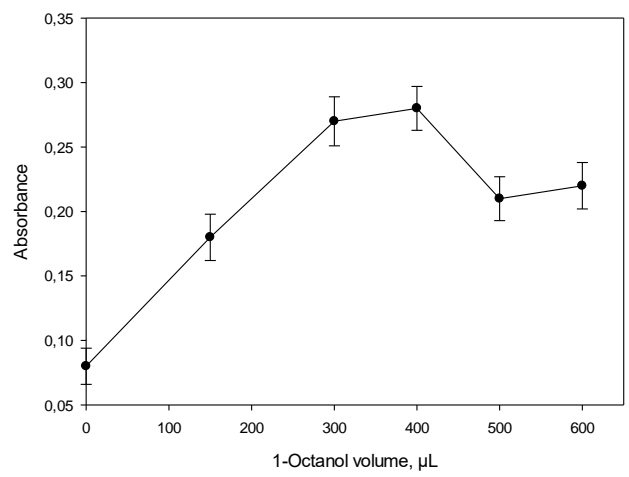

Figure 4. Effect of 1-octanolvolume on absorbance of tartarazine 
Quantitative results could not be obtained when dispersive solvent volume was low. The reason for this is that there is not enough dispersive solvent in the medium to disperse the [C8MIM][BF4]. The highest absorbance values were obtained in the range of $300-400 \mu \mathrm{L}$ of 1-octanol. At higher 1octanol volumes, there was a partial reduction in absorbance. So, $300 \mu \mathrm{L}$ of 1 -octanol was selected as the optimum value for higher absorbance and easy phase separation.

\subsection{Effect of ultrasonication time}

Ultrasonication is an important variable that accelerates phase separation. The ultrasoundinduced cavitation makes the ionic liquid molecules in the aqueous phase move faster. Selection of appropriate ultrasonic time is essential for extraction. The effect of ultrasonic time on the absorbance of the tartrazine was investigated in the range of 1-20 min. As shown in Figure 5, quantitative absorbances were obtained in a $5 \mathrm{~min}$ ultrasound. In addition, over $10 \mathrm{~min}$ of ultrasound absorbance decreased. In later studies, $5 \mathrm{~min}$ of ultrasonication time was selected as the optimum value for higher absorbance and easy phase separation.

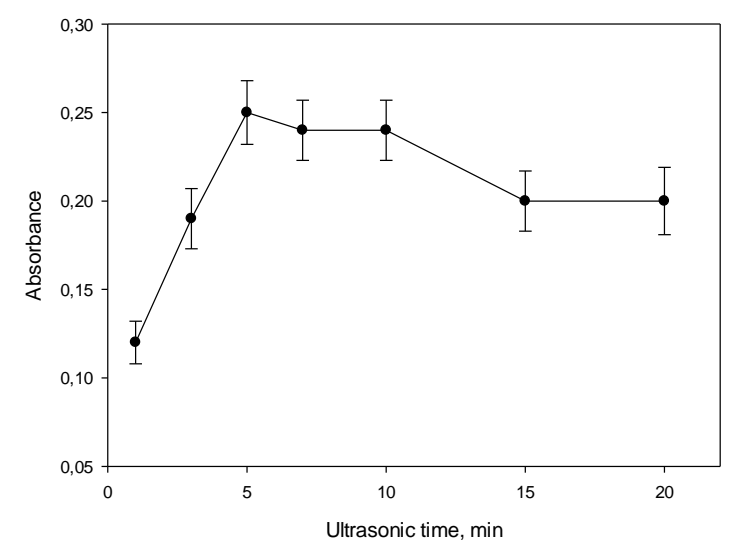

Figure 5. Effect of ultrasonic time on absorbance of tartarazine

\subsection{Effect of temperature}

Studies have been reported to provide phase separation at room temperature for ionic liquids. Additional experimental steps are implemented to increase the phase separation of ionic liquid. Some of them are vortexes, heating, and ultrasonic effect, or a combination thereof. In this study, the heating effect is used to accelerate the phase separation of ionic fluid. And the effect of the working temperature on the absorbance of the tartrazine was investigated from room temperature to $60^{\circ} \mathrm{C}$. The results were given in Figure 6. The highest absorbance was obtained at $45^{\circ} \mathrm{C}$. The reason for the decrease in absorbance at high temperatures is the decrease in the effectiveness of the ionic liquid and dispersive solvent mixture. So, temperature $\left(45^{\circ} \mathrm{C}\right)$ was selected as the optimum value for higher absorbance and easy phase separation.

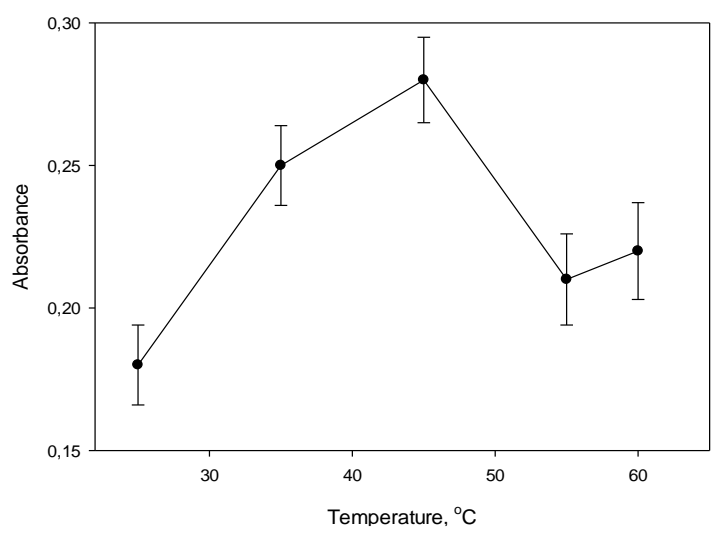

Figure 6. Effect of temperature on absorbance of tartarazine

\subsection{Selectivity study}

The selectivity of the analyte method is expressed as the interest of the selected chemical medium to the analyte in the sample medium. The higher the selectivity, the less analytical method has less interference. In general, experimental studies are performed with model solutions while developing a chemical method. The ability of the method developed when the real example is studied is not known. For this reason, it is necessary to carry out a selection study before the analysis of the real samples. These studies were carried out as follows. First, foreign ions at different proportions were added to the model solutions, and then the ability of the proposed method was tested in the presence of foreign ions by applying the proposed method. If an ion causes a $\pm 5 \%$ change in the absorbance of the analyte, the ion is defined as an interference ion. In addition, the tolerance limits for the corresponding ion were determined by the ratio of the concentration caused by the interference to the 
initial amonuts of tartrazine. The result of the study was given in Table 1. The results indicate no significant interference effect. Second, the analytical properties of the method were determined by studies on matrix matched solutions.
The impact of all possible initiatives was reflected in all analytical data. Studies have shown that the selected chemical medium was highly selective for the tartrazine.

\begin{tabular}{cccc}
\hline Table 1. Selectivity of the method in the presence of potential interfering species and tolerance limits \\
\hline Interfering species & Tolerance limits & Recovery $(\%)$ & RSD $(\%)$ \\
\hline $\mathrm{Sn}^{2+}$ & 1000 & 94.7 & 2.1 \\
$\mathrm{Cd}^{2+}$ & 1000 & 96.4 & 2.4 \\
$\mathrm{~K}^{+}$ & 1000 & 98.1 & 2.2 \\
$\mathrm{Co}^{2+}$ & 1000 & 95.3 & 2.1 \\
$\mathrm{Mg}^{2+}$ & 1000 & 96.2 & 2.0 \\
$\mathrm{Ca}^{2+}$ & 750 & 96.8 & 2.8 \\
Tartaric acid & 750 & 97.5 & 2.5 \\
Ponceau 4R & 750 & 96.5 & 2.6 \\
$\mathrm{Fe}^{3+}$ & 750 & 98.2 & 1.8 \\
$\mathrm{SO}^{2-}$ & 500 & 94.4 & 2.7 \\
Allura red AC & 500 & 95.9 & 2.5 \\
Ascorbic acid & 500 & 97.1 & 2.6 \\
Al & & 96.3 & 2.9 \\
Brilliant Blue & 500 & 96.5 & 2.5 \\
Sunset yellow & 250 & 93.4 & 2.4 \\
Erythrosine & 250 & 93.1 & 2.1 \\
Carmoisine & 250 & 92.4 & 2.8 \\
Amaranth & 100 & 92.5 & 2.5 \\
\hline
\end{tabular}

\subsection{Analytical performance}

After both chemical variables and experimental conditions were optimized, the analytical parameters of the method were determined in selected chemical conditions. The working matrix was performed on matched solutions. The experimental steps were as follows. Different amounts of tartarazine were added to the prepared samples, and then the recommended method was applied. Analytical properties such as the working linear range, regression equation, detection limit (LOD), quantification limit (LOQ), preconcentration factor, sensitivity improvement factor (SIF) and recovery were calculated from the results. The linear working range of the method was calculated as $10-700 \mu \mathrm{g} \mathrm{L}^{-1}$. The SIF was calculated from the slope ratio of the calibration graphs before and after the UA-IL-FODME procedure, and was found as 127 . The LOD and LOQ were expressed as the ratio of three and ten times the standard deviation of the blank samples to the slope of the calibration graph. The LOD and LOQ values were $3.2 \mu \mathrm{g} \mathrm{L}^{-1}$ and $10 \mu \mathrm{g} \mathrm{L}^{-1}$, respectively. Comprehensive analytical data was given in Table 2.

Table 2. Analytical parameters of the proposed method under optimum conditions

\begin{tabular}{cc}
\hline Parameters & For matrix-matched solutions \\
\hline Regression equation & Abs. $=0.0018 \times\left[\right.$ Taratizine, $\left.\mu \mathrm{g} \mathrm{L}^{-1}\right]+0.00024$ \\
Correlation coefficient, $\mathrm{r}^{2}$ & 0.9935 \\
Working linear range, $\mu \mathrm{g} \mathrm{L}^{-1}$ & $10-700$ \\
LOD,$\left(\mu \mathrm{g} \mathrm{L}^{-1}\right)$ & 3.2 \\
LOQ $\left(\mu \mathrm{g} \mathrm{L}^{-1}\right)$ & 10 \\
Average RSD $\%$ & 2.2 \\
Average Recovery $\%$ & 96.1 \\
sensitivity improvement factor $(\mathrm{SIF})$ & 127 \\
Pre-concentration factor $(\mathrm{PF})$ & 50 \\
\hline
\end{tabular}




\subsection{Validation study}

The validation parameters (accuracy and precision) of the proposed method should be tested prior to the analysis of the real samples. Accuracy is expressed as the proximity of the experimental results to the actual accepting value. and the accuracy of the method was tested by recovery experiments. Precision refers to the proximity of the values found in an experiment. The precision of the method was assessed by the presence of relative standard deviation (RSDs\%) value. The test of these parameters was evaluated with intra-day and inter-day studies. Both studies were tested for three different concentrations of tartarazine. Intra-day study, triplicate experimental study was carried out in one day for each concentration. In inter-day study, three repetitive studies were continued in three consecutive days. The RSD\% values for intra-day and inter-day study ranged between 1.8$3.5 \%$ and $2.2-3.8 \%$, respectively. In addition, quantitative recoveries (95.4-103.2\% for intra-day 93.3-105.2\% for inter-day) were obtained for both studies.

\subsection{Application}

After all the analytical parameters of the method were tested, the applicability of the method was evaluated for the extraction and determination of taratizine from the soft drinks and foodstuff. Taking $1.0 \mathrm{~mL}$ of the prepared samples as described in Section 2.3, the recommended method was applied, and the amount of tartarazine in each sample was determined separately. Recovery experiments were also performed. Analytical results are given in Table 3 .

Table 3. Analytical results of the proposed method

\begin{tabular}{|c|c|c|c|c|}
\hline \multirow[t]{2}{*}{ Sample } & \multicolumn{2}{|c|}{ Tartarazine $\left(\mu \mathrm{g} \mathrm{L}^{-1}\right)$} & \multirow[t]{2}{*}{ Recovery \% } & \multirow[t]{2}{*}{$\mathrm{RSD} \%$} \\
\hline & Added & Found & & \\
\hline \multirow[t]{3}{*}{ Syrup-preserved fruit } & - & 75.4 & - & 1.4 \\
\hline & 100 & 170.7 & 95.3 & 1.7 \\
\hline & 200 & 269.0 & 96.8 & 1.8 \\
\hline \multirow{4}{*}{$\begin{array}{l}\text { Carbonated drink- } \\
\text { green }\end{array}$} & - & 117.5 & - & 2.1 \\
\hline & 100 & 219.7 & 102.2 & 2.4 \\
\hline & 200 & 320.9 & 101.7 & 2.5 \\
\hline & - & 321.0 & - & 1.8 \\
\hline \multirow{2}{*}{$\begin{array}{l}\text { Carbonated drink- } \\
\text { orange }\end{array}$} & 100 & 417.4 & 96.4 & 1.7 \\
\hline & 200 & 516.6 & 97.8 & 1.9 \\
\hline \multirow{3}{*}{$\begin{array}{l}\text { Chocolate candy- } \\
\text { green }\end{array}$} & - & 166.0 & - & 1.7 \\
\hline & 100 & 259.8 & 93.8 & 1.8 \\
\hline & 200 & 358.2 & 96.1 & 2.1 \\
\hline \multirow{4}{*}{$\begin{array}{c}\text { Chocolate candy- } \\
\text { yellow }\end{array}$} & - & 245.1 & - & 1.8 \\
\hline & 100 & 340.8 & 95.7 & 2.0 \\
\hline & 200 & 442.9 & 98.9 & 2.1 \\
\hline & - & 450.0 & - & 1.8 \\
\hline \multirow[t]{3}{*}{ Lollipop } & 100 & 511.4 & 101.4 & 2.1 \\
\hline & 200 & 652.0 & 101.0 & 2.2 \\
\hline & - & 314.7 & - & 2.3 \\
\hline \multirow[t]{2}{*}{ Icing sugar } & 100 & 414.7 & 96.6 & 2.1 \\
\hline & 200 & 510.3 & 97.8 & 2.0 \\
\hline
\end{tabular}

The amount of tartrazine ranged from 75.4-321 $\mu \mathrm{g}$ $\mathrm{L}^{-1}$ for the soft drinks and ranged from 166 to 450 $\mu \mathrm{g} \mathrm{L^{-1 }}$ for foodstuff. Furthermore, the RSD\% and recovery values for soft drinks and foodstuff samples were 1.4-2.5\%, 95.3-102.2\% and 1.7$2.3 \%$, 93.8-101.4\%, respectively. In order to understand the positive aspects of the proposed method in literature, the method used was compared analytically with the other methods reported. The analytical properties compared were the operating range, detection limit, preconcentration factor, $\mathrm{RSD} \%$ and recovery. When the Table 4 was examined, it was understood that the proposed method has a wider working 
range and a lower detection limit than other methods. According to other extraction methods, in this study, more environmentally friendly and cheap chemicals were used. In the determination step, the use of cheap and easy to use spectrophotometer that can be found in almost any laboratory is alternative to expensive and complex techniques such as HPLC.

Table 4. Comparison of analytical performance of the proposed method with other methods.

\begin{tabular}{cccccc}
\hline Extraction & Detection technique & $\begin{array}{c}\text { Linearity } \\
\left(\mu \mathrm{g} \mathrm{L}^{-1}\right)\end{array}$ & $\begin{array}{c}\text { Detection } \\
\text { limit }\left(\mu \mathrm{g} \mathrm{L}^{-1}\right)\end{array}$ & $\begin{array}{c}\text { RSD } \\
(\%)\end{array}$ & References \\
\hline IL-DPME & HPLC & $0.5-2000$ & 0.15 & 4.7 & {$[23]$} \\
Without & Electrochemical sensor & $9-549$ & 2.7 & 6.8 & {$[24]$} \\
extraction & Spectrophotometry & $0-10$ & - & 4.2 & {$[25]$} \\
Without & & & & & \\
extraction & HPLC & $1.00-80$ & 1.0 & 6.1 & {$[26]$} \\
IEME & Spectrophotometry & $0.05-5.00$ & 37.19 & 3.2 & {$[27]$} \\
CPE & Spectrophotometry & $10-700$ & 3.2 & 2.2 & This study \\
UA-IL-FODME & & & & & \\
\hline
\end{tabular}

Ionic liquid dispersive phase microextraction (IL-DPME), high-performance liquid chromatography (HPLC), in-tube electromembrane extraction (IEME), ultrasound-assistedionicliquid-basedfloatingorganicdropletsmicroextraction (UA-IL-FODME)

\section{CONCLUSION}

In this study, a simple, innovative and inexpensive ultrasound-assisted ionic liquid-based floating organic droplets microextraction (UA-ILFODME) method was proposed for the extravasation of synthetic food dye tartarazine in soft drinks and foodstuff. The amount of tartarazine was determined by spectrophotometer. The extraction of taratizine was provided in the mixture of ionic liquid ([C8MIM][BF4]) and dispersive solvent (1-octanol) at $\mathrm{pH} 5.5$. The ultrasonic bath temperature during extraction was $45^{\circ} \mathrm{C}$. The most important advantages of the method were the use of chemicals in $\mu \mathrm{L}$ levels to ensure extraction. The use of environmentally friendly, inexpensive chemical and experimental material, rapid extraction, wide linear range, low detection limit are other outstanding advantages of the method. Detailed selectivity and validation studies were performed. The method was successfully applied to the extraction and determination of the tartarazine in selected samples. The results of recovery and $\mathrm{RSD} \%$ were acceptable.

\section{REFERENCES}

[1] Amin K. A., Hameid H.A. and Elsttar A.A. Effect of food azo dyes tartrazine and carmoisine on biochemical parameters related to renal, hepatic function and oxidative stress biomarkers in young male rats. Food Chem. Toxicol., 48-10 (2010) 2994-2999.

[2] Ghoreishi S.M., Behpour M. and Golestaneh M. Simultaneous determination of sunset yellow and tartrazine in soft drinks using gold nanoparticles carbon paste electrode. Food chem., 132-1 (2012) 637-641.

[3] Kucharska M. and Grabka J. A review of chromatographic methods for determination of synthetic food dyes. Talanta, 80-3 (2010) 10451051.

[4] Soponar F., Moţ A.C. and Sârbu C. Quantitative determination of some food dyes using digital processing of images obtained by thin-layer chromatography. J. Chromatogr. A, 1188-2 (2008) 295-300.

[5] Hajimahmoodi M., Afsharimanesh M., Moghaddam G., Sadeghi N., Oveisi M.R., Jannat B. and Kanan H. Determination of eight synthetic dyes in foodstuffs by green liquid chromatography. Food Additives \& Contaminants: Part A, 30-5 (2013) 780-785.

[6] El-Sheikh A.H. and Al-Degs Y.S. Spectrophotometric determination of food dyes in soft drinks by second order multivariate calibration of the absorbance spectra-pH data matrices. Dyes Pigm., 97-2 (2013) 330-339.

[7] Alves S.P., Brum D.M., Andrade E.C.B. and Netto A.D.P. Determination of synthetic dyes in selected foodstuffs by high performance liquid 
chromatography with UV-DAD detection. Food Chem., 107-1 (2008) 489-496.

[8] Andrade F.I., Guedes M.I.F., Vieira Í.G.P., Mendes F.N.P., Rodrigues P.A.S., Maia C.S.C. and Matos L. Determination of synthetic food dyes in commercial soft drinks by TLC and ionpair HPLC. Food Chem., 157 (2014) 193-198.

[9] Li X.Q., Zhang Q.H., Ma K., Li H.M. and Guo Z. Identification and determination of 34 watersoluble synthetic dyes in foodstuff by high performance liquid chromatography-diode array detection-ion trap time-of-flight tandem mass spectrometry. Food Chem., 182 (2015) 316-326.

[10] Asfaram A., Ghaedi M. and Goudarzi A. Optimization of ultrasound-assisted dispersive solid-phase microextraction based on nanoparticles followed by spectrophotometry for the simultaneous determination of dyes using experimental design. Ultrason. Sonochem., 32 (2016) 407-417.

[11] Song X., Shi Z., Tan X., Zhang S., Liu G. and $\mathrm{Wu} \mathrm{K}$. One-step solvent exfoliation of graphite to produce a highly-sensitive electrochemical sensor for tartrazine. Sens. Actuators, B., 197 (2014) 104-108.

[12] Ma M., Luo X., Chen B., Su S. and Yao S. Simultaneous determination of water-soluble and fat-soluble synthetic colorants in foodstuff by high-performance liquid chromatographydiode array detection-electrospray mass spectrometry. Journal of Chromatography A, 1103-1 (2006) 170-176.

[13] Qi P., Zeng T., Wen Z., Liang X. and Zhang X. Interference-free simultaneous determination of Sudan dyes in chili foods using solid phase extraction coupled with HPLC-DAD. Food Chem., 125-4 (2011) 1462-1467.

[14] Long C., Mai Z., Yang X., Zhu B., Xu X., Huang $X$. and Zou X. A new liquid-liquid extraction method for determination of 6 azodyes in chilli products by high-performance liquid chromatography. Food Chem., 126-3 (2011) 1324-1329.

[15] Altunay N., Elik A., Bulutlu C. and Gürkan R. Application of simple, fast and eco-friendly ultrasound-assisted-cloud point extraction for pre-concentration of zinc, nickel and cobalt from foods and vegetables prior to their flame atomic absorption spectrometric determinations. International journal of environmental analytical chemistry, 98-7 (2018) 655-675.

[16] Yan H., Qiao J., Pei Y., Long T., Ding W. and Xie, K. Molecularly imprinted solid-phase extraction coupled to liquid chromatography for determination of Sudan dyes in preserved beancurds. Food Chem., 132-1 (2012) 649-654.

[17] Chen D., Li X., Tao Y., Pan Y., Wu Q., Liu Z. and Yuan Z. Development of a liquid chromatography-tandem mass spectrometry with ultrasound-assisted extraction method for the simultaneous determination of sudan dyes and their metabolites in the edible tissues and eggs of food-producing animals. Journal of Chromatography B, 939 (2013) 45-50.

[18] Elik A. Ultrasonic-assisted leaching of trace metals from sediments as a function of $\mathrm{pH}$. Talanta, 71-2 (2007) 790-794.

[19] Altunay N., Elik A. and Gürkan R. Extraction and reliable determination of acrylamide from thermally processed foods using ionic liquidbased ultrasound-assisted selective microextraction combined with spectrophotometry. Food Additives \& Contaminants: Part A, 35-2 (2018) 222-232.

[20] Elik A., Altunay N. and Gürkan R. Microextraction and preconcentration of $\mathrm{Mn}$ and $\mathrm{Cd}$ from vegetables, grains and nuts prior to their determination by flame atomic absorption spectrometry using room temperature ionic liquid. J. Mol. Liq., 247 (2017) 262-268.

[21] Elik A., Altunay N. and Gürkan R. UltrasoundAssisted Low-Density Solvent-Based Dispersive Liquid-Liquid Microextraction Coupled to Spectrophotometry for the Determination of Low Levels of Histamine in Fish and Meat Products. Food Anal. Methods., 12-2 (2019) 489-502.

[22] Altunay N., Elik A. and Gürkan R. Extraction and reliable determination of acrylamide from thermally processed foods using ionic liquidbased ultrasound-assisted selective microextraction combined with spectrophotometry. Food Additives \& Contaminants: Part A, 35-2 (2018) 222-232. 
[23] Wu H., Guo J.B., Du L.M., Tian H., Hao C.X., Wang Z.F. and Wang J.Y. A rapid shakingbased ionic liquid dispersive liquid phase microextraction for the simultaneous determination of six synthetic food colourants in soft drinks, sugar-and gelatin-based confectionery by high-performance liquid chromatography. Food Chem., 141-1 (2013) 182-186.

[24] Gan T., Sun J.Y., Meng W., Song L. and Zhang Y.X. Electrochemical sensor based on graphene and mesoporous $\mathrm{TiO} 2$ for the simultaneous determination of trace colourants in food. Food Chem., 141 (2013) 3731-3737.

[25] El-Sheikh A.H. and Al-Degs Y.S. Spectrophotometric determination of food dyes in soft drinks by second order multivariate calibration of the absorbance spectra-pH data matrices. Dyes Pigm., 97 (2013) 330-339.

[26] Bazregar M., Rajabi M., Yamini Y. and Asghari A. In-tube electro-membrane extraction with a sub-microliter organic solvent consumption as an efficient technique for synthetic food dyes determination in foodstuff samples. Journal of Chromatography A, 1410 (2015) 35-43.

[27] Nambiar A.P., Sanyal M. and Shrivastav P.S. Performance evaluation and thermodynamic studies for the simultaneous cloud point extraction of erythrosine and tartrazine using mixed micelles in food samples. Food Anal. Methods., 10 (2017) 3471-3480. 